\begin{tabular}{lc}
\hline & ANNALES \\
& UNIVERSITATIS MARIAE CURIE-SKŁODOWSKA \\
LOL. V & SECTIO N \\
\hline
\end{tabular}

ISSN: 2451-0491 • e-ISSN: 2543-9340 • CC-BY 4.0 • DOI: 10.17951/en.2020.5.23-43

\title{
Myślenie w systemie poznawczym i w świecie wartości. O powinnościach dydaktyki w dobie neuronauki
}

\section{Thinking in the Cognitive System and in the World of Values. On the Duties of Teaching in the Age of Neuroscience}

\author{
Aneta Grodecka \\ Uniwersytet im. Adama Mickiewicza w Poznaniu. Wydział Filologii Polskiej i Klasycznej \\ ul. Fredry 10, 61-701 Poznań, Polska \\ grodecka@amu.edu.pl \\ https://orcid.org/0000-0003-3685-6911
}

\begin{abstract}
Starting from the contemporary determinants of changes in the field of mental operations, such as the transcultural nature of the world and neuroscientific concepts of mind (Francisco Varela, Daniel C. Dennett, Gilles Fauconnier, Mark Turner), the author shapes the foundations of mental didactics, recreates clues related to cognitive mechanisms in Polish language didactics (Maria Nagajowa, constructivism, new media), and continues to present such fields of teaching activity sensitive to shaping thinking as: interpretation, rhetoric, discursive manners and perceptual exercises, leading to the exposure of qualia. "Mental didactics" proposed in the article means integrated training of thinking, perception, attention and value system.
\end{abstract}

Keywords: neuroscientific concepts of mind; didactics; thinking; value system; perception

\footnotetext{
Abstrakt. Wychodząc od współczesnych determinantów zmian w zakresie operacji myślowych, takich jak transkulturowy charakter świata i neuronaukowe koncepcje umysłu (Francisco Varela, Daniel C. Dennett, Gilles Fauconnier, Mark Turner), autorka kształtuje podstawy dydaktyki mentalnej, odtwarza tropy związane z mechanizmami poznawczymi w dydaktyce polonistycznej (Maria
} 
Nagajowa, konstruktywizm, nowe media) oraz wskazuje takie pola aktywności nauczycielskiej wrażliwe na kształtowanie myślenia, jak: interpretacja, retoryka, kultura dyskusji i ćwiczenia percepcyjne, prowadzące do odsłonięcia qualiów. Zaproponowana w artykule „dydaktyka mentalna” oznacza zintegrowane kształcenie myślenia, percepcji, uwagi i systemu wartości.

Słowa kluczowe: neuronaukowe koncepcje umysłu; dydaktyka; myślenie; system wartości; percepcja

Nie ma ani jednego myślenia, ani wspólnego wszystkim myślenia o myśleniu. Wyróżnia się liczne odmiany myślenia, takie jak: analityczno-krytyczne, pożądane w kulturze Zachodu; prelogiczne, charakterystyczne dla ludów pierwotnych; scholastyczne, polegające na ujmowaniu świata w kategoriach teologicznych; kreatywne - to jeden ze współczesnych edumitów ${ }^{1}$; zdroworozsądkowe i potoczne, kojarzone z mądrością ludową. Wymienia się także m.in. myślenie obrazami, naukowe i metodyczne, filozoficzne i kontemplacyjne, spiskowe i lateralne. Trudno wyliczyć i omówić w jednym miejscu wszystkie obowiązujące systemy myślenia ${ }^{2}$, dlatego nie to jest moim celem. Za ważniejsze problemy uznaję namysł nad tym, w jakim stopniu myślenie zmienia się w ramach odkryć neuronauki, czy styl myślenia wiąże się z aksjologią, czy sposób rozumowania - kształtowany w szkołach - wpływa na formowanie wzorców osobowych oraz czy kształcenie umysłu jest powinnością polonistycznej dydaktyki.

Myślenie, rozum i intelekt to pojęcia opisujące zdolności, które - w przeciwieństwie do zmysłowości - uznawane były za pierwiastek ludzki, odróżniający od zwierząt. Pogląd ten już w starożytności budził spory i zadecydował o ukształtowaniu dwóch starogreckich stylów myślenia. Pierwszy z nich okazał się w kulturze europejskiej dominujący - to styl dualistyczny (różnicujący), obecny w poglądach Parmenidesa, Platona i Arystotelesa. W tym stylu rozum, prawdę i obiektywizm przeciwstawiono emocjom, złudzeniom i materii. Drugi

1 Określenie edumit oznacza fałszywe przekonania na temat rzeczywistości. W edukacji funkcjonują pojęcia neuromit i psychomit (Szczygieł i Cipora 2014). Dydaktyka kreatywna to kierunek kształcenia oparty na dawnym podziale funkcjonalnym mózgu, który pozbawiony jest obecnie jakichkolwiek podstaw naukowych. Człowiek z urodzenia jest jednostką twórczą, a jego stopień rozbudzenia twórczego nie zależy od edukacji, lecz raczej od warunków życiowych i wsparcia rodziny. Edumit w postaci kreatywnej dydaktyki był odpowiedzią na dominujący w edukacji styl myślenia analityczno-krytycznego.

2 Katarzyna Polus-Rogalska (2002) podzieliła myślenie na pojęciowe i wyobrażeniowe, wyróżniając w pierwszej grupie: myślenie potoczne, dziecięce, logiczne, filozoficzne, racjonalne, empiryczne i naukowe, konkretne i abstrakcyjne, probabilistyczne, twórcze. Zgodnie z założeniami psychologii poznawczej autorka wskazała na interakcję pomiędzy systemem pojęciowym i przestrzennym (wyobrażeniowym) w ludzkim umyśle. 
styl myślenia (Heraklit i stoicy), bliski filozofii hebrajskiej oraz myśli Wschodu, wyrósł z przekonania o jedności świata i włączył w krąg poznania również sferę doznań i doświadczeń. Dominacja dualizmu upowszechniła przekonanie, że doświadczenie można przekroczyć, to intelekt bowiem triumfuje nad materią. Ważnym spadkobiercą tego poglądu był Kartezjusz. Trafna jest następująca rekonstrukcja Marka Szulakiewicza:

[...] trzeba było dziesiątków lat sporów i dyskusji, abyśmy zrozumieli, że podmiot, który myśli o sobie jak o źródle własnych przedstawień i działań, w rzeczywistości wcale nie jest człowiekiem. Kartezjańska teza „myślę wiec jestem” zafałszowuje też obecność świata. Jeśli bowiem obecność ta jest tylko za pośrednictwem podmiotu, to świata nie doświadczamy w sposób właściwy, lecz tylko przez nasze myślenie, które nie ma obiektywnego charakteru. (Szulakiewicz 2012: 209)

Zmiana myślenia o myśleniu, która następowała stopniowo, posiłkowała się odkryciami behawiorystów, psychiatrów, a w ostatnim czasie uległa neurologicznej rewolucji. Czy te zmiany znajdują odzwierciedlenie w przestrzeni kultury, na poziomie wzorców osobowych i mentalnych? Spróbuję to rozważyć.

Inteligencja, którą psychologia ujmuje w zróżnicowany sposób, nadal w potocznym sensie utożsamiana jest ze sprawnością intelektualną (Garstka 2016). W kulturze funkcjonuje dość starodawny ideał osobowy intelektualisty - to ożywiony wzorzec literacki z czasów oświecenia, dopełniony atrybutami z zakresu technologii informacyjnych, wyposażony w stosunkowo prosty zestaw cech i poglądów, takich jak: niechęć wobec przeszłości, mitów i przesądów; pogarda wobec niesprawnych intelektualnie; szybkie reakcje; skłonność do analizowania i wartościowania (kategoryzowania). Gloryfikacja intelektu powoduje, że osoby, które dysponują innymi rozbudzonymi funkcjami poznawczymi, sytuują się na słabszych pozycjach. Wiemy, że rozwinięta percepcja cechuje artystów, rozbudzone czucie - poetów, a intuicja - osoby niewykształcone, jednak to „myślenie”, z uwagi na to, że umożliwia zdobycie dobrej pozycji zawodowej i finansowej, ciągle uznawane jest za najważniejsze w systemie mentalnym. W ujęciu Allana D. Blooma wzorzec intelektualisty związany jest z filozoficznym dyskursem, jaki stworzył w przeszłości John Locke, według którego człowiek miał rodzić się jako czysta, niezapisana karta i wybierać z natury jedynie te pierwiastki, które uzna za niezbędne do stworzenia umowy społecznej. Za przeciwieństwo takiego dyskursu Bloom uznał styl myślenia Jana Jakuba Rousseau, według którego człowiek miał rodzić się pierwotnie dobry, uznawać naturę za odległą, ale i pociągającą, a także ulegać oddziaływaniu prawideł społecznych powodujących jego rozszczepienie i dramat. Bloom związał z obiema strategiami określone wzorce osobowe: 
Locke jest autorem naszych instytucji, uzasadnia nasze przywiązanie do własności prywatnej i wolnej wymiany oraz daje nam poczucie naszych praw człowieka. Myśl Rousseau kryje się za większością dominujących poglądów na to, czym jest życie i jak należy leczyć rany. Locke uczy, że przystosowanie do społeczeństwa obywatelskiego jest niemal automatyczne; Rousseau, że bardzo trudne i wymaga przeróżnych pośredników pomiędzy społeczeństwem a utraconą naturą. Uosobieniem tych doktryn są dwie charakterystyczne postacie naszych czasów. Rzutki, optymistyczny, skuteczny, trzeźwy ekonomista to spadkobierca Locke'a; głęboki, zamyślony, melancholijny psychoanalityk to typ Russowski. (Bloom 1997: 202-203)

To ciekawa konstatacja. W przypadku pierwszego wzorca myślenie ma charakter praktyczny, $\mathrm{w}$ drugim zaś nie prowadzi do szybkich rezultatów, co jednak nie oznacza, że jest irracjonalne i głupie, raczej przypomina - jak określił to Michał Heller - „myślenie poplątane”:

Myślenie wielu ludzi jest poplątane (nieprzejrzyste). Nawet najbardziej logicznie myślącym ludziom zdarzają się okresy poplątanego myślenia. A za myśleniem idzie życie. Dlatego życie tak często bywa poplątane. Filozofia może być sposobem na życie tylko wtedy, gdy jest w stanie przyczynić się do jego rozplątywania, to znaczy czynienia go bardziej przejrzystym. (Heller 2017: 64)

Według dyskursu Hellera myśliciel to osoba, która dysponuje umysłem nakierowanym na racjonalność, która niekoniecznie zmierza do praktycznych rozwiązań i umowy społecznej, gdyż efekty pracy racjonalnego umysłu bywają znacznie bardziej poważne. Heller wylicza prawidła racjonalności (odwołam się do nich poniżej), dzięki czemu przywołuje dawny model Locke’a i aktualizuje go w nowoczesny sposób.

Współcześnie „myślenie o myśleniu” ulega istotnym modyfikacjom. Ważną rolę odgrywa tu zmiana cywilizacyjna. Dzięki nowym środkom komunikacji świat staje się otwarty, interkulturowy, a to sprawia, że myślenie kultury Zachodu przechodzi obecnie próbę czasu³, świat Wschodu zaś, który już dawno pogodził się $\mathrm{z}$ destrukcją podmiotu, staje się ważnym partnerem dla europejskich myślicieli.

3 W dydaktyce takie stanowisko owocuje kategorią „inności”, która bywa rozmaicie traktowana. Literackie świadectwa związane z tą kategorią przeanalizowała Iwona Morawska (2018), wskazując na konieczność pogłębionej lektury, której efektem jest wieloraka aktywność umysłowa (zarówno werbalna, jak i pozawerbalna) oraz wsparcie podmiotu w jego dążeniach do samowiedzy. 
Francisco Varela, który stworzył podstawy filozofii zarażonej neuronauką, uznawał - co ważne - buddyzm za manifestację aktywnej i metodycznej fenomenologii ${ }^{4}$. W sferze mentalnej, po odrzuceniu schematów wynikających z podejścia formalnego, dokonano wielu ważnych odkryć oraz dostrzeżono złożone zjawiska, uznawane za mieszaniny pojęciowe ${ }^{5}$, operacje umysłowe, $\mathrm{w}$ dużej mierze nieświadome, które decydują o rozpoznawaniu znaczeń i o aktach naszej kreatywności. Nikt nie rozdziela już logiki i imaginacji - uznajemy, że obie sfery były bogacone na drodze ewolucji i są w równym stopniu aktywne w naszym umyśle. Odkrycia neurologów prowadzą nie tylko do zmian w systemie poznawczym, lecz także pośrednio przyczyniają się do rewizji zasad moralności i prawa oraz zmieniają kwestie odpowiedzialności za czyny, wolną wolę i empatię (Churchland 2013). Coraz częściej mówi się o splocie myślenia i systemu wartości. Przytoczę kilka obserwacji. Tomasz Czub zakłada, że „niewiedzenie” może być wartościowym stanem umysłu i powołuje się na zdanie Lwa S. Wygotskiego, że świadomość - oparta na znaczeniach - podlega wielu ograniczeniom. Brak refleksji jest jego zdaniem szczególnie pożądany w umyśle psychologa, który prowadzi terapię pacjenta i dąży do osiągnięcia z nim stanu idealnej interakcji. Rezygnacja z uświadomionej wiedzy oraz nieformułowanie oczekiwań stają się elementami postawy etycznej; chodzi o sytuację wyostrzoną, gdy człowiek nie jest przedmiotem badań, lecz ich niepowtarzalnym podmiotem ${ }^{6}$ (Czub 2009). W związku z odkryciem, że procesy myślowe nie przebiegają w równym tempie, „myślenie, pamięć i postawy funkcjonują na dwóch poziomach (świadomym i celowym oraz nieświadomym i automatycznym)" (Myers 2004: 18); coraz większe zainteresowanie budzi mechanizm popełniania błędów. Dysponujemy wiedzą o mechanizmach fałszywych przekonań i omyłek, które kierują nami w sposób automatyczny, a to stopniowo prowadzi do zmian w postawach nauczycieli oraz wpływa na procesy kształtowania i weryfikowania wiedzy (Pawlicki 2016). Z uwagi na system wartości ważne okazują się obserwacje dotyczące sfery emocji. David G. Myers konstatuje:

Ciało migdałowate wysyła więcej sygnałów neuronowych do kory, niż otrzymuje. Dzięki temu naszym odczuciom łatwiej jest kierować myśleniem niż myśleniu rządzić uczuciami. [...] W lesie podskakujemy na szelest liści, zostawiając korze

4 Filozof był organizatorem seminariów z udziałem Dalajlamy, podczas których poszukiwano zrębów interkulturowego myślenia o świadomości, śnie i nieświadomości (Varela red. 2001).

5 Termin wprowadzony przez kognitywistów - Gillesa Fauconniera i Marka Turnera (2019: 599), według których mieszaniny pojęciowe: „identyfikacja, integracja, imaginacja - to podstawowe, tajemnicze, pełne mocy, złożone i w większości nieświadome operacje, które stanowią sedno nawet najprostszego znaczenia".

6 Uwagi na temat stanu niewiedzy mogą dotyczyć także umysłu nauczyciela. 
mózgowej późniejsze rozstrzygnięcie, czy dźwięk pochodził od drapieżnika czy był to tylko wiatr. (Myers 2004: 68)

Pomiędzy poznaniem a emocjami dochodzi do splotu, sfera emocji okazuje się jednak nieprzewidywalna i niełatwa do wykorzystania w sposób metodyczny; prawdopodobnie przypisywaliśmy jej dotąd, dość pochopnie, zawyżone funkcje. Badania psychologów potwierdzają związek myślenia z uwagą i systemem wartości. Według prawidłowości opisanych przez Alinę Kowalczyk (red. 2014: 10) „myślenie, zarówno to lękiem podszyte, obronne, jak i odważne, twórcze, zależy przede wszystkim od wartości, jakimi kieruje się człowiek. Od stanu uwagi na przykład jej zakresu i »szczelności« - zależy sposób myślenia intuicyjny lub refleksyjny".

Nowo odkryte determinanty myślenia stanowią dobry przyczynek do zmian w dydaktyce. Zanim wskażę możliwe rozwiązania, przyjrzę się stworzonym wcześniej koncepcjom. O myśleniu pisano w dydaktyce często i chętnie. W poradniku dla początkujących nauczycieli autorstwa Marii Nagajowej (1990: 124-126) utrwalono przekonanie, że operacje myślowe (autorka wymieniła abstrahowanie, analizę i syntezę, dedukcję i indukcję, porównywanie, rozumowanie, uogólnianie) można rozwijać za pomocą odpowiednich zabiegów metodycznych. Myślenie zostało podzielone na: abstrakcyjne, dywergencyjne, konkretne (obrazowe), konwergencyjne, logiczne, nieproduktywne, produktywne (twórcze), refleksyjne (krytyczne), sensoryczno-motoryczne (zmysłowo-ruchowe), wyobrażeniowo-pojęciowe (tamże: 81-83). Wykład inspirowany był popularnymi wówczas tezami psychologii rozwojowej (Nagajowa odwołała się do następujących pozycji: Bruner 1974; Piaget i Inhelder 1967), a opis technik uczenia się został zapożyczony z publikacji Jarosława Rudniańskiego ${ }^{7}$. Trudno oczekiwać, by to omówienie zachowało aktualność w kontekście neuronauki. Nagajowa, nie wspominając o intuicji, związała sposób myślenia z wiekiem ucznia i poziomem ilorazu inteligencji. Obecnie wiemy, że myślenie sensoryczne i wyobrażeniowe nie dotyczy jedynie grupy niemowląt i dzieci w młodszym wieku szkolnym, a procesy integracji sensorycznej i wielozmysłowej syntezy są procesami uniwersalnymi, utrzymującymi się przez całe życie. Wiemy również, że dywergencja nie jest charakterystyczna jedynie dla uczniów mających uzdolnienia twórcze i wysoki iloraz inteligencji, a myślenie dywergencyjne nie jest jedynym skutecznym sposobem zapewniającym trwałość wiedzy.

7 Fragmenty książki Rudniańskiego (1963), która doczekała się ośmiu wydań, trafiły na karty podręcznika dla klasy piątej szkoły podstawowej autorstwa Marleny Derlukiewicz (2012). 
Dywergencja stała się modnym tematem rozpraw dydaktycznych, gdy zaczęto proklamować metody projektowe i częste stały się odwołania do konstruktywizmu. Przypomnijmy, że chodzi o rodzaj teorii uczenia się, wywodzący się z książki Nelsona Goodmana (1997), który w zakresie procesów poznawczych wyróżnił szereg operacji intelektualnych (składanie i rozkładanie, wartościowanie, porządkowanie, usuwanie i dodawanie, deformowanie), a za ważny mechanizm regulujący myślenie, podlegający reakcjom automatycznym, uznał kategoryzowanie. Ten element neuronaukowy zaważył na atrakcyjności całej propozycji. Tezy Goodmana na polu edukacji spopularyzował Bruner (2010), formułując na ich podstawie nową, psychokulturową koncepcję umysłu. Uznał, że trzeba przestać traktować umysł jak urządzenie do przeprowadzania operacji (teoria komputacyjna) i dostrzec w nim sieć interakcji. Obecnie wiemy, że w zaproponowanej koncepcji kryła się przesada, która okazała się „ślepą uliczką". Bruner wykluczył zjawiska przyrodnicze; założył, co było błędem, że nie warto badać podstaw świata i natury substancji, takie tematy trzeba pozostawić teologii. Obecnie wiemy, że myślenie nie jest jedyną drogą do osiągnięcia poznania ${ }^{8}$, podczas rekonstrukcji umysłu uwzględnia się bowiem również badania nad naturą snu, objawień, medytacją i buddyzmem. Konstruktywizm nie spełnił pokładanych w nim oczekiwań. Jak zauważył Geoff Petty (2013: 14): „Z teorią poznawczą, nazwaną konstruktywizmem, zgadzają się niemal wszyscy [podkr. - A.G.] specjaliści od ludzkiego mózgu i umysłu". Łatwo znajdziemy zwolenników neuronauki, dla których takie stanowisko jest ograniczone. Będą to np. badacze języka, którzy uznają, że przekazywane kulturowo doświadczenie i świadome uczucia są jedynie ozdobami, czymś w „rodzaju lukru na emocjonalnym torcie” (LeDoux 2000: 360). Nie można zaprzeczyć, że konstruktywizm okazał się dla dydaktyki przydatny, umocnił w niej bowiem dwie ważne zasady: wiązania wiedzy z uprzednią wiedzą ucznia oraz nauczania pojęć w sposób problemowy. Tezy kierunku stały się w pewnym momencie bardzo atrakcyjne dla dydaktyków nauk ścisłych, ponieważ pozwalały im zerwać z modelem, który obowiązywał w tych naukach od zawsze, opisywanym jako model bezpośredniego nauczania pojęć $c^{9}$ (Jantz 1994). Dydaktycy matematyki (Dylak 2014) zaczęli postulować tryb nauczania, który ma się zaczynać od analizy przykładów i antyprzykładów, a kończyć - sformułowaniem definicji. Czy szkolnych

8 Wskazał na ten fakt Józef M. Bocheński (1992: 16), który zasugerował, że „myśleniu” trzeba nadać szerszy zakres. Dowodził, że „rozumiemy przez nie pewien ruch duchowy (geistige Bewegung) od jednego przedmiotu do drugiego. Tego rodzaju ruch nie musi być jednocześnie poznawaniem. Możemy także myśleć w ten sposób, że w wolnej chwili przypominamy sobie po kolei pewne rzeczy. Zgodnie z tym poznawanie należałoby ująć jako poważne myślenie, którego celem jest wiedza”.

9 Nauczanie pojęcia zaczynało się od podania definicji, potem zaś następowało analizowanie przykładów i antyprzykładów, a na końcu - sprawdzenie znajomości pojęcia. 
polonistów trzeba namawiać do przyjęcia takiego sposobu nauczania? Zdarza się, że rozpoczynają lekcję od definicji bajki lub impresjonizmu i dopiero potem analizują z uczniami „przykłady” gatunku i kierunku, uznając inny sposób dochodzenia do wiedzy za zbyt energetyczny. Mają wybór. Sądzę, że szkodliwa może okazać się przesada, gdyż jeden sposób myślenia nie wyklucza innego (zob. diagram 1). Warto pamiętać, że już Thomas S. Kuhn (1985) zakładał, iż uczony w badaniach podstawowych powinien myśleć zarówno dywergencyjnie (rozbieżnie), jak i konwergencyjnie (zbieżnie), czyli powinien być zarazem obrazoburcą i tradycjonalistą.

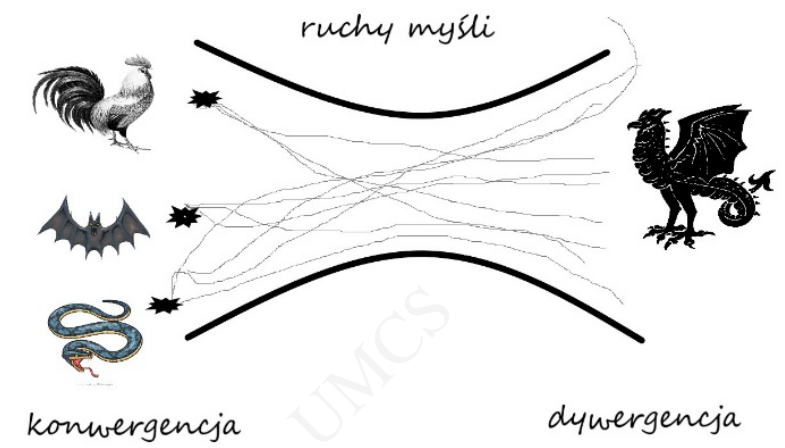

Diagram 1. „Ruchy myśli”. Myślenie konwergencyjne i dywergencyjne Źródło: opracowanie własne.

Zainteresowanie myśleniem spowodowały zmiany w kulturze medialnej, związane z nowymi środkami komunikacji. Marshall McLuhan (1975) spopularyzował pogląd o radykalnej zmianie, jaką typ przekaźnika miał wprowadzić w sferze intelektualnego funkcjonowania człowieka. Według jego poglądów wpływ telewizji miał być równie silny jak narodziny pisma w czasach starożytności greckiej; telewizja miała osłabiać tradycyjne myślenie, ponieważ zaprojektowany w jej ramach odbiór wizji nie wymagał - podobnego jak w trakcie czytania - zaangażowania intelektu. Twierdzenia McLuhana były dość oczywiste i zawierały wiele nieścisłości. Z pewnością nie jest tak, jak proponował, że każdy przekaz telewizyjny zakłada odbiór bierny. Nie jest też prawdą, że odbiór tego typu przekazów powoduje w każdym przypadku stępienie krytycyzmu i wzrost stereotypów; na szczęście „otępiałość umysłowa telewidzów" (Patzlaff 2008) nie dotyka wszystkich użytkowników telewizji. Badacz podczas tworzenia koncepcji opierał się na badaniach neurofizjologów nad funkcjonalnym zróżnicowaniem półkul mózgowych, ale traktował je dość swobodnie. Jak zauważyła Mirosława Marody (1987: 113), część jego obserwacji była zgodna z badaniami empirycznymi, a część była nieuzasadniona, jak np. przypisanie oka lewej półkuli, ucha zaś prawej, choć wiadomo, że 
obie półkule kontrolują jedno i drugie. Diagram opracowany na podstawie jego poglądów, pokazujący wpływ „oka” i „ucha” na umysł (zob. diagram 2), spopularyzowała Ewa Kuryluk (1977), przedrukowała go Marody (1987: 114), na końcu wykres trafił do dydaktyki - licealiści mogli zapoznać się z nim w podręczniku kształcenia językowego (Milewska i Milewska 2002: 31).

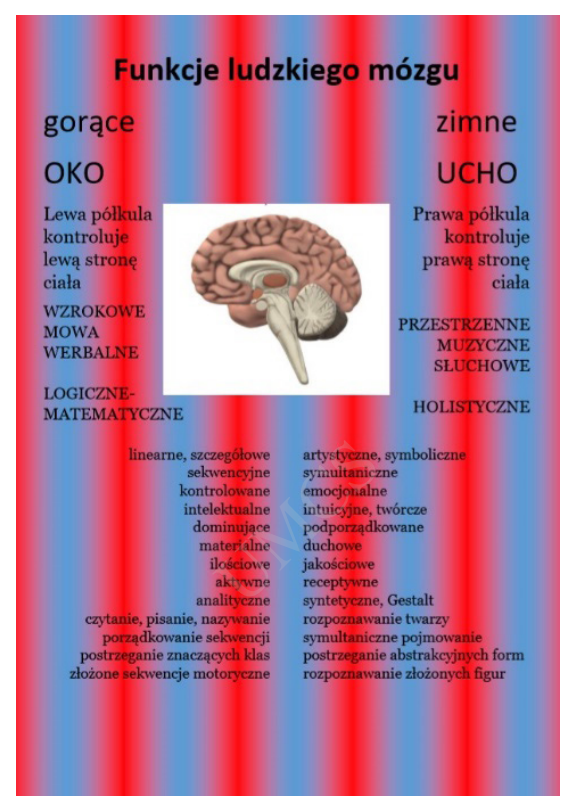

Diagram 2. Funkcje ludzkiego mózgu w koncepcji Marshalla McLuhana Źródło: opracowanie własne na podstawie (Marody 1987).

Koncepcja zakorzeniła się i nikt jej nie weryfikował, diagram utrwalał się w edukacji jako jeden z bardziej trwałych edumitów dotyczących kreatywności. Pewne nadzieje związane z rozwojem umysłu mogła budzić idea ścieżek edukacyjnych, propagowana w szkołach w latach 1999-2008, gdy w ramach ścieżki czytelniczo-medialnej sformułowano ważne cele związane z pracą samokształceniową i wykorzystaniem mediów jako narzędzia pracy intelektualnej. W praktyce ścieżka ta nie cieszyła się popularnością wśród autorów opracowań metodycznych; została związana z wiedzą o kulturze mediów, kształceniem umiejętności tworzenia prezentacji, przemówień i opisów bibliograficznych ${ }^{10}$. Szkoda.

10 Do rzadkości należały takie pomysły programów szkolnych, jak np. Czytam, pamiętam, rozumiem Jolanty Krupińskiej (2006). Opracowując techniki pracy umysłowej, autorka odwoływała się do literatury fachowej na temat mózgu, pamięci i koncentracji. 
Obecnie, w związku z dominacją komputerów i narodzinami nowych technik komunikacyjno-informatycznych, kwestia umysłu stała się ponownie istotna. Autorzy kształtujący edukację medialną rozważają, w jaki sposób nowoczesne komunikatory i multimedialne środowisko mogą wspomóc dydaktyków. Wiąże się z tym zagadnieniem wiele wątpliwości. Przekazy medialne (Siemieniecki 2012), które zwyczajowo posługują się prostym kodem dostosowanym do potrzeb odbiorcy, raczej nie stanowią pouczającego wyzwania. Zasobność Internetu przerasta ludzką wydolność. Z pewnością lektura zebranych tam materiałów może rozwijać umysł, ale głównie w jego dyspozycji analityczno-krytycznej. Krytycy mediów podtrzymują, że gaszą one naszą zdolność do kreowania żywych i bogatych wyobrażeń, wielozadaniowość źle wpływa na naszą zdolność koncentracji i uwagi, a media mogą prowadzić do "odczulenia mózgu” (braku umiejętności rozpoznania i rozumienia intencji innych osób). Cenny z punktu widzenia dydaktyki neurofeedback - stan spójności fal mózgowych z rytmem serca - jest trudny do uzyskania podczas lekcji. Zwolennicy mediów twierdzą, że niektóre $\mathrm{z}$ gier komputerowych ${ }^{11}$ mogą stać się właśnie środkiem prowadzącym do wyciszenia i uspokojenia umysłu, mogą poprawiać uwagę w stanach niewidzenia oraz wzmacniać koordynację wzrokowo-ruchową. Podobne twierdzenia są empirycznie potwierdzone, z czym nie wypada dyskutować, trudno jednak pozbyć się przekonania na temat ograniczonych możliwości wykorzystania gier w szkolnej praktyce. Pojawia się wątpliwość, czy uczniowie mają uczestniczyć w tych grach w trakcie lekcji; gdy studenci zaczynają wykorzystywać aplikacje typu Kahoot! i Mentimeter do opracowywania quizów sprawdzających uwagę i pamięć widzów prezentacji, dysponują nowymi możliwościami (Patrick 2009). Zakłada się, że gry mogą uczyć ortografii i przybliżać lektury, ale efekty oddziaływania gry zależą nie tylko od jej rodzaju, lecz także od wrodzonych zdolności gracza, w związku z tym niektóre, z pozoru niewinne, gry fabularne mogą wprawiać ucznia w stan paranoicznej czujności, uczyć go szybkich i gwałtownych reakcji.

Czy kształcenie myślenia można w ogóle uznać za powinność dydaktyki? W jakim stopniu „myślenie” wywołuje system wartości? Czy kształtując umysł ucznia, wkraczamy jednocześnie na ścieżkę formowania jego światopoglądu? Odkrycia neuronauki sugerują dydaktykom, by wyjść poza kompetencje myślenia analityczno-krytycznego. Nie dla wszystkich jest to oczywiste. Według diagnozy Andrzeja Zybały (2016) nasza edukacja wciąż ma kłopoty z nauczaniem myślenia krytycznego, co stanowi pokłosie polskiej historii naznaczonej romantycznym

11 Zdania na temat wpływu gier komputerowych na umysł użytkowników są podzielone: „[...] z jednej strony mamy strumień badań twierdzących, że gry uszkadzają umysł, z drugiej mówiących, że zwiększają moc mózgu" (Goleman 2014: 197). 
"obłędem” i wiąże się z tradycją naszego nauczania, które zawsze dalekie było problemom świata i wywodzi się z jezuickich szkół propagujących „ciemnotę" i zabobon. Wypada mi nie zgodzić się z wnioskiem socjologa, który uznał, że jedynym lekiem na zły stan polskiej umysłowości i peryferyjność myślenia jest naśladowanie wzorów Zachodu i nakłanianie młodzieży do krytycznego myślenia. Takie stanowisko to rodzaj uproszczenia. Nie trzeba przywoływać tu neuronaukowych koncepcji umysłu, wystarczy przypomnieć, że każda kultura - jak konstatował Leszek Kołakowski (1972) - potrzebuje dwóch porządków myślenia: technologiczno-naukowego i mityczno-metafizycznego. Paradygmat kształtowania intelektu został osłabiony przez odkrycia neurologów i nie powinien dłużej ograniczać edukacji. Uważam, że trzeba kształcenie umysłu traktować szerzej. W ramach holistycznie pojmowanego umysłu myślenie jest jedynie jedną z władz poznawczych, a logika i metafora - jak trafnie ujęli to Gilles Fauconnier i Mark Turner (2019: 602) - to takie same operacje poznawcze, posługują się bowiem tymi samymi mechanizmami odwzorowania i miksowania. Wychodząc naprzeciw podobnym oczekiwaniom, nakreślę poniżej trzy zasady, które określiłam mianem „ABC dydaktyki mentalnej”.

\section{A. Uczeń myśli samodzielnie}

Samodzielność myślenia to dość starodawne zagadnienie dydaktyczne. Wincenty Okoń poświęcił mu jedną ze swych pierwszych rozpraw - Problem samodzielności myślenia i działania (1957), w której przywołał amerykański termin myślenie produktywne ${ }^{12} \mathrm{i}$ uznał myślenie samodzielne za jego polski odpowiednik. Zdefiniował owo myślenie jako „proces dochodzenia do nowych wiadomości poprzez formułowanie problemów, ich rozwiązywanie i weryfikację rozwiązań" (Okoń 2003: 181). Uznał również, że taki proces wymaga wysiłku, pamięci, twórczego napięcia wyobraźni i wnikliwej obserwacji. Opisał prawidło, zgodnie z którym im wyższy stopień samodzielności uczniów, tym wyższy poziom ich kompetencji. Nie wspomniał, co obecnie jest ważne, że w procesie dochodzenia do wiedzy istotne jest też popełnianie błędów, mogą one bowiem otwierać kolejne ścieżki poszukiwań i pełnić funkcję stymulującą myślenie. W dydaktyce polonistycznej istnieje przestrzeń, której rozmiary służą popełnianiu „szczęśliwych” błędów - jest nią „interpretacja” ${ }^{13}$. Polonista, który przynosi na lekcję gotowe roz-

12 Termin ten upowszechnił Max Wertheimer (1945).

13 O otwarcie szkolnej przestrzeni interpretacyjnej upominają się m.in. Krystyna Koziołek (2017) i Grażyna B. Tomaszewska (2019). 
wiązania, stosuje terror strukturalistyczny i zasadę profesjonalnego czytania oraz dyktuje uczniom notatki o utworach, z pewnością nie rozwinie ich umysłów. Takie kompetencje może zapewnić m.in. „czytanie ponad tekstem”, „czytanie przeciw tekstowi”, przekład intersemiotyczny, wszelkiego rodzaju „czytanie otwarte”, którego nie ograniczają wybory testowe i pytania sterujące - o druzgocącej naturze tych ostatnich pisała Barbara Myrdzik (2015), zachęcając polonistów do mądrej perswazji w trakcie formułowania poleceń i zadań do lektury.

\section{B. Uczeń w roli naukowca}

Często wskazuje się obecnie na niedobory myślenia logicznego wśród uczniów, nie wspominając jednocześnie o tym, że logika (nauka o poprawnym myśleniu) oraz erystyka (sztuka wygrywania sporów za pomocą chwytów wykorzystujących błędy logiczne) nie są już przedmiotami w szkołach kształcących nauczycieli. Potrzeba powrotu do myślenia naukowego jest tematem toczących się współcześnie dyskusji. Z jednej strony słychać głosy sceptyków, którzy zastanawiają się, dlaczego uczeń ma występować w roli naukowca, widzą bowiem w tym ograniczenie jego kreatywności, z drugiej zaś słychać argumenty przemawiające za powrotem do retoryki i jej zasad kształcenia. Brak porozumienia $\mathrm{w}$ kwestiach podstawowych, jak sądzę, związany jest z pokłosiem dawnego modelu naukowości, opartego na myśleniu analityczno-krytycznym, który wykluczał udział indukcji i intuicji - władz uznanych za podejrzane w ramach psychologii marksistowskiej. Wielu dydaktyków dyskutujących o edukacji jeszcze nie porzuciło dawnych wyobrażeń - ich wiedza o umyśle sięga pism Jeana Piageta, przez co w sposób ograniczony postrzegają zakres możliwego odstępstwa od krytycznej analizy. Na pytanie, jak ma wyglądać współczesne myślenie racjonalne, odpowiada Heller (2017: 37-41), który sformułował kilka podstawowych zasad. W ramach jego wykładu logika łączy się z altruizmem, wyobraźnią i systemem wartości. Zasady obejmują:

1) dążność do ścisłości i informatywności w formułowaniu sądów i wypowiedzi w granicach języka, co ma stać w opozycji do - nierzadko nawet zamierzonego - „mętniactwa wypowiedzi”,

2) otwartość na dyskusję z innymi, która wymaga postawy zrozumienia dla poglądów przeciwnych,

3) samokrytycyzm - być dla siebie dyskutantem bezlitosnym,

4) krytyczne rozpatrywanie innych możliwości,

5) wewnętrzną spójność poglądów związaną z poczuciem konsekwencji,

6) świadomość ograniczeń językowych i innych uwarunkowań własnych poglądów. 
Nic dodać, nic ująć. W dydaktyce polonistycznej zasady racjonalności są kształtowane. Retorykę przywołano w nowych podstawach programowych kształcenia, zarówno dla szkoły podstawowej, jak i dla liceum ogólnokształcącego. W dokumentach dla pierwszego etapu kształcenia zaplanowano podstawowe umiejętności w zakresie formułowania argumentów, ich hierarchizowania, m.in. podział na argumenty odwołujące się do logiki, faktów i emocji (egzamin ósmoklasisty). Na kolejnym etapie edukacji wprowadzono rozprawkę opartą na rozważaniu problemu (egzamin maturalny - poziom rozszerzony), przyznając umiejętnościom z zakresu inventio charakter wartościujący. Wyliczonym przez Hellera zasadom służą znane w dydaktyce metody: „kapelusze myślowe” i „burza mózgów ${ }^{14}$ oraz rozmaite formy dyskusji (Okraj 2015). Ważne w zakresie kształcenia racjonalności stają się umiejętności tworzenia komentarzy krytycznych (riposty) i rozpoznawania w sztuce figur myśli (metafora, ironia i inne).

Pierwsze zagadnienie związane jest z kulturą dyskusji i - z uwagi na dużą dawkę złych praktyk w środkach masowego przekazu - wymaga szybkiej interwencji dydaktycznej. Chodzi o odpowiedź na pytanie, jak postępować z przeciwnikiem w dyskusji, gdy ten myli się i zachęca nas do polemiki. Riposta daje się opisać w formie hasła słownikowego (Jankowicz 2019), ma rozbudowane konteksty kulturowe i swoich mistrzów (jak np. Sokrates), zasadza się na pomysłowości i nie jest łatwą techniką komunikacji. Jak nauczyć ripostowania? Odpowiedzi na to pytanie udziela Daniel C. Dennett, który utworzył reguły komentarza krytycznego i nazwał je regułami Rapoporta. Autor ten zapożyczył strategię postępowania od psychologa społecznego i związał ją z badaniami nad altruizmem. Według tych reguł uczestnik debaty powinien:

1) wyrazić stanowisko przeciwnika tak jasno, dokładnie i sprawiedliwie, aby powiedział on: „Dziękuję, żałuję, że nie pomyślałem, aby ująć to w ten sposób",

2) wyliczyć wszystkie punkty sporne (zwłaszcza jeśli nie są one przedmiotem ogólnej czy powszechnej zgody),

3) wspomnieć o wszystkim, czego nauczył się od swego przeciwnika.

Tylko wtedy uczestnik debaty ma prawo wypowiedzieć choć jedno słowo krytyki lub podjąć próbę odrzucenia krytykowanego stanowiska (Dennett 2015: 51).

14 Za twórcę „burzy mózgów” uznaje się Alexa F. Osborna. Rodowód metody sięga XVI wieku. W kulturze indyjskiej (Prai-Barshana, gdzie Prai oznacza 'poza sobą, a Barhana - 'pytanie’) zalecano, by mnożenie pomysłów oddzielać wyraźnie od dyskusji (i przeprowadzać ją na następny dzień). Według praktyki brainstormingu, opisanej przez Osborna, wartością metody są pytania stymulujące heurezę. Badacz wymienił ich ponad pięćdziesiąt; główne pytania były zogniskowane wokół operacji: zastosować inaczej, zaadaptować, zmodyfikować, powiększyć, zmniejszyć, dokonać substytucji, przegrupować, odwrócić, połączyć (Osborn 1953). 
O tym, jak ważne są wyliczone powyżej reguły, przekonałam się w trakcie zajęć ze studentami polonistyki. Gdy po wysłuchaniu wystąpienia mieli podjąć polemikę i zredagować samodzielnie komentarze krytyczne, wszyscy postępowali podobnie: albo tworzyli karykatury stanowiska przeciwnika, dyskutowali z konkretnymi argumentami, albo w ogóle nie podejmowali dialogu i jedynie formułowali własne stanowisko związane z tematem. Po zastosowaniu reguł Dennetta redagowali już inne riposty, zrozumieli bowiem, że to od nich zależy, czy ich przeciwnik stanie się słuchaczem otwartym na krytykę, a wyważona ocena jego poglądów może uczynić go bardziej podatnym na manipulację $e^{15}$.

Rozumienie metafor zostało już wpisane w skład powinności dydaktycznych. Obowiązują tu jednak dość starodawne przekonania dotyczące związku myślenia metaforycznego z fazami rozwoju mentalnego, które stały się w przeszłości podstawą podziału szkół (do gimnazjum mieli trafiać uczniowie zdolni do myślenia metaforycznego, a do szkoły podstawowej - uczniowie myślący w sposób konkretny). Poloniści długo odwoływali się do ustaleń Ewy Guttmejer (1982) i teorii stadiów rozwoju Piageta ${ }^{16}$, postępując zgodnie z zasadą, że rozwój dziecka jest motywowany jedynie wewnętrznie, myślenie metaforyczne kształtuje się około 12. roku życia, a kolejne stadia rozwoju są osiągane niezależnie od otoczenia. Współcześnie to już uległo zmianie. Na podstawie badań empirycznych (Muszyńska 1999) uznaje się, że każdy z rodzajów myślenia ${ }^{17}$ jest obecny w całym procesie rozwoju. Na wczesnym poziomie nauczania można spotkać uczniów wyposażonych w kompetencje rozumienia metafor, których umysły kształtowane są w dobrym domowym zapleczu, czemu często towarzyszą nowe przekazy medialne. Można spotkać także wielu ludzi dojrzałych, w których umysłach metafora pozostaje nieaktywna, co odsłaniają świadectwa odbioru sztuki. Anna Matuchniak-Krasuska (1999), analizując recepcję obrazów Jerzego Dudy-Gracza, zacytowała opinię widza, który kpi z malarza, gdyż zauważył, że w scenie ukrzyżowania artysta umieścił obraz Matki Boskiej Częstochowskiej (ten zaś został namalowany znacznie później, na pewno nie w czasach Chrystusa). Wprawdzie cytowany komentarz dotyczy obrazu religijnego, a to sfera, gdzie $z$ trudem akceptuje się przedstawienia niekanoniczne, ale ilustruje on jednocześnie poglądy na sztukę „odbiorców kalekich” lub „ludzi pozbawionych pojęcia

15 Studentom obce były działania podstępne, wykluczali skuteczność swoich wystąpień krytycznych.

16 Piaget wyodrębnił cztery stadia rozwoju: sensoryczno-motoryczne (niemowlęctwo), przedoperacyjne (wczesne dzieciństwo), operacji konkretnych (średnie dzieciństwo), operacji formalnych (adolescencja).

17 Bruner wyróżnił myślenie enaktywne, ikoniczne i symboliczne. 
metafory". O rozumieniu metafor nie decyduje jedynie uposażenie biologiczne - gdy zawodzi domowe zaplecze, wiele zależy od dydaktyków. Niepokojący jest fakt, że bariery odbioru, wyszczególnione w latach 80 . XX wieku przez Zenona Urygę (1982), uległy współcześnie poszerzeniu o „barierę metafizyczno-symboliczną" (Szymik 2005), co może oznaczać, że kształtowanie rozumienia metafory przemieszcza się z zakresu podstawowych zadań dydaktycznych do sfery zadań trudnych i wymagających odpowiedniego przygotowania metodycznego. Neurolodzy ostrzegają, że myślenie metaforyczne zawiera zasadzkę, zagraża mu bowiem analogia:

Orzekanie o cechach jednej skomplikowanej rzeczy przez odniesienie do cech innej skomplikowanej rzeczy, którą już rozumiesz (a przynajmniej tak ci się wydaje), jest słynnym i potężnym narzędziem do myślenia, lecz jest ono tak potężne, że często prowadzi myślicieli na manowce, gdy ich wyobraźnia zostaje schwytana przez zdradziecką analogię. (Dennett 2015: 13-14)

Mimo tego, co stwierdzono powyżej, poloniści rzadko poświęcają rozumieniu metafor odrębne zajęcia - szkoda, bo zajmują oni uprzywilejowaną pozycję w gronie dydaktyków, moga prowadzić ćwiczenia na bazie metafor słownych i obrazowych, zakodowanych w sztuce, a ich artystyczna jakość zapewnia dobre efekty kształcenia. Uczniowskie próby tłumaczenia metafor, połączone z zapisywaniem wniosków natury semantycznej, to ćwiczenia żmudne, ale niezbędne.

Równie trudnym zadaniem dydaktycznym okazuje się inna zasada racjonalności wymieniona przez Hellera. Jak bowiem nakłonić ucznia, by był dla siebie „dyskutantem bezlitosnym”? Jak wpoić mu umiejętności autokrytycyzmu i autoironii? Ironiczni potrafimy być najczęściej wobec innych. Coraz bardziej obce w mentalnym świecie stają się drwina i szyderstwo z samego siebie. W tym miejscu posłużę się przykładem, gdyż autoironia - jako środek wyrazu - często pojawia się w sztuce i, nierozpoznana, poszerza obszar nierozumienia twórczości artystycznej. Duda-Gracz był obiektem wielu błędnych interpretacji, jednak to jego Autoportret (Ora et colabora) z 1982 roku zaowocował komentarzem, w którym nierozpoznanie autoironii stało się podstawą niesprawiedliwego osądu jego postawy światopoglądowej.

Obraz (ryc. 1), zatytułowany prześmiewczo Ora et colabora, przedstawia malarza w roli błazna, ze sporym brzuchem, ubranego w czapkę z gazety, ustrojonego w odznaczenia państwowe i religijne. Autoironia, którą zastosował malarz, to rodzaj ramy, w której integrują się różne elementy; nie obowiązuje tu proste prawo analogii. Dzieło powstało w Częstochowie, w stanie wojennym, podczas pleneru poświęconego jubileuszowi obrazu Matki Boskiej, gdy artysta malował 
również portrety papieskie, portrety tamtejszych zakonników (także późniejszego zleceniodawcy Golgoty jasnogórskiej - o. Jana Golonki). W błędnej interpretacji obrazu, zanotowanej na kartach leksykonu, wysunięto na pierwszy plan kwestię zależności malarza od władzy i ustroju komunistycznego, odczytując mylnie wykorzystane w obrazie atrybuty (Chrzanowska-Pieńkos, Pieńkos red. 1996). Artystę ta interpretacja ubodła, o czym wspomniał w kalendarium swej twórczości (Duda-Gracz 2001). Autorami wywodu o obrazie nie byli uczniowie i amatorzy, lecz zawodowcy i historycy sztuki, których trudno podejrzewać o tendencyjność czy złą wolę. Sądzę, że zadecydowało błędne rozpoznanie - odznaczenia państwowe i czapka z Trybuny Robotniczej zostały odczytane jako argument odnoszący się do faktów, a nie jako argument odnoszący się do sfery emocji.

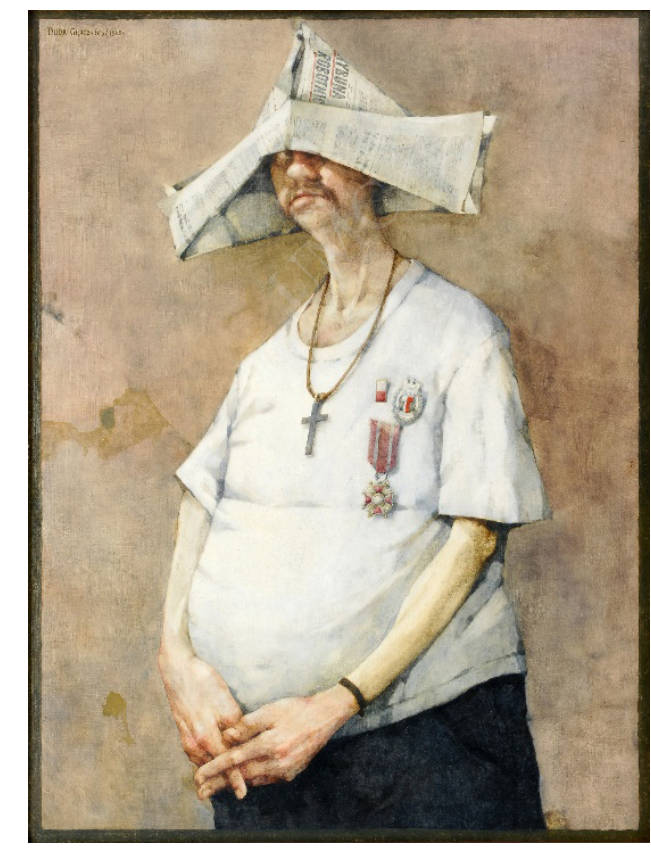

Ryc. 1. J. Duda-Gracz, Autoportret (Ora et kolabora), 1982, olej na płycie pilśniowej, 80 x 60,5 cm

Źródło: Muzeum Narodowe we Wrocławiu.

\section{Uczeń z wyobraźnią}

W wypowiedziach na temat sztuk plastycznych wyrażano przekonanie, że polegają one na „myśleniu obrazami”, obrazy mogą stać się podstawą poznania. Obecnie myślenie wzrokowe uległo poszerzeniu - mówi się o równoległości 
doznań wzroku, ruchu i kształtu, a sztukę traktuje się jako twór wielozmysłowy. Badania neurologów potwierdzają, że „sztuka, jej odbiór i jej tworzenie, są immanentnymi i swoistymi cechami natury ludzkiej i są czynnikami aktywującymi całość działania mózgu" (Vetulani 2010: 14). Jerzy Vetulani dowodził, że sztuka może spotęgować uwagę poznawczą, czyli „umiejętność skupienia się na bodźcach intelektualnych przez czas wystarczający do ich zakodowania i zapisania w pamięci roboczej" (tamże: 11). Co ważne, wskazywał, że uwagę poznawczą można trenować $\mathrm{w}$ różny sposób - w takim samym stopniu rozwija ją zarówno uczenie działalności artystycznej, jak i sam kontakt ze sztuką. W odniesieniu do lekcji języka polskiego ważny jest ten drugi rodzaj treningu. Rzadko uczniowie występują w roli ilustratorów, częściej zaś stają się badaczami sztuki. W kształceniu umiejętności odbioru estetycznego ważną rolę odgrywają qualia, dlatego rozważę ich dydaktyczną przydatność. Na pytanie, czym są qualia, w obrazowy sposób odpowiedziała Wioletta Dziarnowska:

Qualia to jakościowo określone odczucie dostępne pierwszoosobowo, towarzyszące zachowaniom większości istot żywych. Pragmatyczne przykłady qualiów czerpane są zwykle z opisów doznań percepcyjnych. I tak quale wzrokowe to np. doznawana głęboka czerwień świeżej truskawki czy doświadczana jaskrawość różu jedwabnej koszuli, quale słuchowe to jazgoczący dźwięk wydawany przez cykady czy szemrzący odgłos górskiego strumienia. Do qualiów zalicza się także doznania somatyczne, np. odczucie rwania towarzyszące bólowi czy swędzenie po ukłuciu komara, doznania emotywne, takie jak życzliwa akceptacja związana z uczuciem sympatii, irytacja przy wybuchu gniewu, a także doznania wolitywne, np. nieustępliwość potrzeby czy determinacja przy dokonywaniu wyboru. Tak pojęte qualia składają się na świadomość fenomenalną. (Dziarnowska 2005: 36)

Sądy na temat qualiów są podzielone. Filozof Wilfrid Sellars uznaje, że „dzięki qualiom warto żyć” (za: Dennett 2015: 120), Dennett zaś traktuje je sceptycznie - omawiając ustalenia współczesnej neurokognitywistyki, przywołał przypadki patologii rozumienia, które przeczą schematom percepcji, jak np. prozopagnozja, gdy zaburzeni poznawczo mają bezpośredni dostęp do qualiów wzrokowych, ale nie potrafią ich rozpoznać jako quale doświadczane (tamże). Podobne zaburzenia moga zachodzić podczas percepcji kolorów, gdy reakcje emocjonalne i reakcje związane z uwagą dotyczącą kolorów są odwrócone. Te wątpliwości zdają się jednak nie przekreślać sensu analizy fenomenologicznej, która otwiera przestrzeń doświadczania i smakowania sztuki. W związku z tym uważam, że organizowanie dla uczniów ćwiczeń percepcyjnych, prowadzących do odsłonięcia qualiów, może przyczynić się do poszerzenia ich sfery mentalnej 
oraz do ukształtowania pogłębionych nawyków postrzegania ${ }^{18}$. Podczas gdy operacje intelektualne i myślenie logiczne przebiegają według szablonów, na poziomie rozpoznawania kolorów wkraczamy w obszar myślenia poplątanego nie możemy zakładać, że kompetencje percepcyjne są monolityczne, a raczej że ulegają podziałom, w trakcie których trudno wskazać konkretne podzbiory czy subkompetencje. Polonista wkracza w obszar doświadczenia, które ma charakter zjawiskowy i nie może go unikać. O wartościach płynących z uruchomienia świadomości qualiów przekonują psychologowie. Agnieszka Cudowska dowodzi:

Im głębsze jest rozumienie tego, co postrzegamy, tym bardziej staje się ono indywidualne, swoiste, jednostkowe. Wierność sobie, akcentowana w fenomenologicznym ujęciu bycia i stawania się człowieka, pozostaje więc także ważną kwestią w realizowaniu twórczych orientacji życiowych. Jest ona jednocześnie istotnym czynnikiem oryginalności myślenia. (Cudowska 2004: 135)

\section{DYDAKTYKA A MYŚLENIE (WNIOSKI)}

W dydaktyce ważne okazuje się nie myślenie, lecz umiejętność korzystania ze wszystkich władz poznawczych. Określenie dydaktyka mentalna, które uznaję za odpowiednie do opisu proponowanych zmian, skupia w sobie zintegrowane kształcenie myślenia, percepcji, uwagi i systemu wartości. W tej sferze wiele jest do zrobienia, zapewne nie wyczerpałam wszystkich możliwości. Uznaję, że „styl myślenia” może być pretekstem do rozmowy o umyśle. Odniesienia do intelektu, zmysłów, czucia i intuicji mogą okazać się ważne w procesie kształcenia aksjologicznego. Indywidualność percepcyjna, pojmowana jako wyróżnik oryginalności, pozwala pogłębiać wiedzę o różnicach międzyludzkich i „inności”. W edukacji amerykańskiej, czego przykładem może być koncepcja Gregory’ego Ulmera (Szkudlarek 2009), splot myślenia racjonalnego i mitycznego już dawno uznano za owocny i kształcący. Przywołana koncepcja zakładała wprawdzie integrację tradycyjnych i medialnych środków przekazu, co nadal uchodzi za trudne $w$ ramach dydaktyki polonistycznej, jednak zaproponowany kierunek kształcenia, czyli intelekt, percepcja i czucie, funkcjonujące jako elementy nowej duchowości, wydaje się możliwy do zaakceptowania.

18 Propozycje ćwiczeń znajdują się w podręczniku Anety Grodeckiej i Anny Podemskiej-Kałuży (2012). 


\section{BIBLIOGRAFIA}

Bloom, A.D. (1997). Umyst zamknięty. O tym, jak amerykańskie szkolnictwo wyższe zawiodto demokrację i zubożyło dusze dzisiejszych studentów. Poznań: Zysk i S-ka.

Bocheński, J.M. (1992). Wspótczesne metody myślenia. Poznań: Wydawnictwo „W drodze”. Bruner, J.S. (1974). Prawidłowości rozwoju. W: tegoż, W poszukiwaniu teorii nauczania. Warszawa: PIW.

Bruner, J.S. (2010). Kultura edukacji. Kraków: Universitas.

Chrzanowska-Pieńkos, J., Pieńkos, A. (red.). (1996). Leksykon sztuki polskiej XX wieku. Sztuki plastyczne. Poznań: Wydawnictwo Kurpisz.

Churchland, P.S. (2013). Moralność mózgu. Co nauka mówi o moralności. Kraków: Copernicus Center Press.

Cudowska, A. (2004). Kształtowanie twórczych orientacji życiowych w procesie edukacji. Białystok: Trans Humana.

Czub, T. (2009). Wartość niewiedzenia. Refleksje na podstawie koncepcji świadomości L.S. Wygotskiego. Poznańskie Studia z Filozofii Humanistyki, nr 8, 367-379.

Dennett, D.C. (2015). Dźwignie wyobraźni i inne narzędzia do myślenia. Kraków: Copernicus Center Press.

Derlukiewicz, M. (2012). Stowa na start! Kształcenie literackie i kulturowe. Warszawa: Nowa Era.

Duda-Gracz, J. (1982). Autoportret(Ora et kolabora). Olej na płycie pilśniowej, 80 x 60,5 $\mathrm{cm}$. Wrocław: Muzeum Narodowe.

Duda-Gracz, J. (2001). Kalendarium „Golgoty jasnogórskiej”. W: tegoż, Golgota jasnogórska. Częstochowa: Paulinianum.

Dylak, S. (2014). Ksztatcenie przez działanie i myślenie. Pobrane z: www.kopernik.org.pl/ fileadmin/user_upload/PROJEKTY_SPECJALNE/Konferencja_Pokazac-Przekazac/ Edycja_2014/Podsumowanie_konf_PP_2014.pdf [dostęp: 6.08.2016].

Dziarnowska, W. (2005). Subiektywna natura świadomości. O funkcjach qualiów. W: M. Urbański, P. Przybysz (red.), Funkcje umystu (s. 29-61). Poznań: Zysk i S-ka.

Fauconnier, G., Turner, M. (2019). Jak myślimy. Mieszaniny pojęciowe i ukryta złożoność umystu. Warszawa: Biblioteka Kwartalnika KRONOS, Fundacja Augusta hr. Cieszkowskiego.

Garstka, T. (2016). Wyszukać (jakąś?) inteligencję. W: tegoż, Psychopedagogiczne mity. Jak zachować naukowy sceptycyzm w edukacji i wychowaniu? (s. 254-281). Warszawa: Wolters Kluwer.

Goleman, D. (2014). Fokus. Sztuka koncentracji jako ukryte dążenie do doskonałości. Poznań: Media Rodzina.

Goodman, N. (1997). Jak tworzymy świat. Warszawa: Aletheia.

Grodecka, A., Podemska-Kałuża, A. (2012). Wielozmysłowość. Filozofia i dydaktyka. Poznań: Wydawnictwo Naukowe Uniwersytetu im. Adama Mickiewicza.

Guttmejer, E. (1982). Rozumienie treści symbolicznych przez dzieci z klas III-V. Czytanie ze zrozumieniem. Warszawa: PWN.

Heller, M. (2017). Jak być uczonym. Kraków: Copernicus Center Press. 
Jankowicz, G. (2019). Riposta. W: Z. Kadłubek, B. Mytych-Forajter, A. Nawarecki (red.), Ilustrowany stownik terminów literackich. Historia, anegdota, etymologia (s. 423427). Gdańsk: słowo/obraz terytoria.

Jantz, R. (1994). Nauczanie pojęć. W: R.I. Arends (red.), Uczymy się nauczać (s. 276-301). Warszawa: WSiP.

Kołakowski, L. (1972). Obecność mitu. Paryż: Instytut Literacki.

Kowalczyk, A. (red.). (2014). Samo się nie myśli. Afekt w procesach poznawczych. Sopot: Smak Słowa.

Koziołek, K. (2017). Czas lektury. Katowice: Wydawnictwo Uniwersytetu Śląskiego.

Krupińska, J. (2006). Czytam, pamiętam, rozumiem. Pobrane z: https://profesor.pl/mat/ pd6/pd6_j_krupinska_20060627.pdf [dostęp: 28.01.2010].

Kuhn, T.S. (1985). Dwa bieguny. Tradycja $i$ nowatorstwo w badaniach naukowych. Warszawa: PIW.

Kuryluk, E. (1977). Artysta sygnałem alarmowym. O spotkaniu z Marshallem McLuhanem. Polityka, nr 48, 10-11.

LeDoux, J.E. (2000). Mózg emocjonalny. Tajemnicze podstawy życia emocjonalnego. Poznań: Media Rodzina.

Marody, M. (1987). Technologie intelektu. Językowe determinanty wiedzy potocznej i ludzkiego dziatania. Warszawa: PWN.

Matuchniak-Krasuska, A. (1999). Publiczność wobec metafory plastycznej. O recepcji groteski Jerzego Dudy-Gracza. Łódź: Uniwersytet Łódzki.

McLuhan, M. (1975). Przekaźniki, czyli przedłużenie człowieka. W: tegoż, Wybór pism (s. 43-194). Warszawa: Wydawnictwa Artstyczne i Filmowe.

Milewska, B., Milewska, I. (2002). Język polski 1. Kształcenie językowe. Gdynia: Wydawnictwo Pedagogiczne Operon.

Morawska, I. (2018). Literatura jako "głos Innego" w przestrzeni edukacyjnej. Annales UMCS sectio N (Educatio Nova), nr 3, 17-36, DOI: http://dx.doi.org/10.17951/ en.2018.3.17-36.

Muszyńska, M. (1999). Metafory w edukacji prymarnej. Koncepcja kształcenia wspomagajacego rozwój zdolności interpretacyjnych dzieci 9-10-letnich. Toruń: Wydawnictwo Uniwersytetu Mikołaja Kopernika.

Myers, D.G. (2004). Intuicja. Jej siła i słabość. Taszów: Moderator Tomasz Witkowski.

Myrdzik, B. (2015). Czy warto czytać? Uczeń jako obiekt zabiegów perswazyjnych w podręcznikach szkolnych dla liceum. W: B. Myrdzik, I. Morawska, M. Latoch-Zielińska (red.), Przestrzenie rzeczywiste $i$ wyobrażone. Metodyczny wielogtos o różnych przestrzeniach (s. 81-94). Lublin: Wydawnictwo UMCS.

Nagajowa, M. (1990). ABC metodyki języka polskiego dla poczatkujacych nauczycieli. Warszawa: WSiP.

Okoń, W. (1957). Problem samodzielności myślenia i działania. Studia Pedagogiczne, nr 4, 7-23.

Okoń, W. (2003). Zasada samodzielności, czyli ograniczonej zależności ucznia od nauczyciela. W: tegoż, Wprowadzenie do dydaktyki ogólnej (s. 180-183). Warszawa: Wydawnictwo Akademickie „Żak”.

Okraj, Z. (2015). Twórcze rozwiazywanie problemów z zastosowaniem nowych technik dyskusji: teoria, badania, trening. Kielce: Uniwersytet Jana Kochanowskiego. 
Osborn, A.F. (1953). Applied Imagination - Principles and Procedures of Creative Thinking. New York: Alex Faickney Osborn.

Patrick, F. (2009). Gry wideo w szkole. Podręcznik dla nauczyciela. Pobrane z: http://89.161.199.96/media/Podrecznik_HandBook_PL.pdf [dostęp: 24.01.2020].

Patzlaff, R. (2008). Zastygłe spojrzenie. Fizjologiczne skutki patrzenia na ekran a rozwój dziecka. Kraków: Oficyna Wydawnicza Impuls.

Pawlicki, A. (2016). Szczęśliwe błędy. Błędy, pomytki i alternatywne koncepcje - jak nie pobładzić, uczac (się) na błędach. Pobrane z: www.edunews.pl/badania-i-debaty/ opinie/3752-szczesliwe-bledy-1 [dostęp: 10.10.2019].

Petty, G. (2013). Nowoczesne nauczanie. Praktyczne wskazówki dla nauczycieli, wykładowców i szkoleniowców. Sopot: GWP.

Piaget, J., Inhelder, B. (1967). Operacje umysłowe i ich rozwój. W: P. Oleron, J. Piaget, B. Inhelder, P. Greco, Inteligencja (s. 189-197). Warszawa: PWN.

Polus-Rogalska, K. (2002). Czy „myśleć” znaczy tylko racjonalnie? Bydgoszcz: Margrafsen Kate.

Rudniański, J. (1963). Jak się uczyć? Warszawa: PZW.

Siemieniecki, B. (2012). Media a patologie we współczesnym świecie. W: B. Bilicka (red.), Wychowanie do wartości w świecie cyberkultury (s. 15-40). Toruń: Wydawnictwo Naukowe Uniwersytetu Mikołaja Kopernika.

Szczygieł, M., Cipora, K. (2014). Fałszywe przekonania na temat działania mózgu i zjawisk psychicznych, czyli neuromity i psychomity w edukacji. Edukacja, nr 2, 53-66.

Szkudlarek, T. (2009). Wiedza i wolność w pedagogice amerykańskiego postmodernizmu. Kraków: Oficyna Wydawnicza Impuls.

Szulakiewicz, M. (2012). Systemy myślenia i człowiek. W: tegoż, O człowieku w czasach trudnych. Urywki filozoficzne (s. 149-232). Toruń: Wydawnictwo Naukowe Uniwersytetu Mikołaja Kopernika.

Szymik, E. (2005). Bariery w odbiorze lektur szkolnych. Nauczyciel i Szkoła, z. 1-2, 181-193.

Tomaszewska, G.B. (2019). Praktyki czytania. Ponowoczesna interpretacja a szkoła. Gdańsk: Wydawnictwo Uniwersytetu Gdańskiego.

Uryga, Z. (1982). Odbiór liryki w klasach maturalnych. Warszawa-Kraków: PWN.

Wertheimer, M. (1945). Productive Thinking. London: Harper \& Brothers.

Varela, F. (red.). (2001). Sen, śnienie, umieranie. Zgtębianie świadomości z Dalaj Lamą. Kraków: „Mudra”.

Vetulani, J. (2010). Mózg: fascynacje, problemy, tajemnice. Kraków: Wydawnictwo Homini.

Zybała, A. (2016). Polski umyst na rozdrożu. Wokót kultury umysłowej w Polsce. W poszukiwaniu źródet niepowodzeń części działań publicznych. Warszawa: Oficyna Wydawnicza SGH. 